\title{
Comparing the fermentation performance of Escherichia coli KO11, Saccharomyces cerevisiae 424A(LNH-ST) and Zymomonas mobilis AX101 for cellulosic ethanol production
}

\author{
Ming W Lau, Christa Gunawan, Venkatesh Balan and Bruce E Dale*
}

\begin{abstract}
Background: Fermentations using Escherichia coli KO11, Saccharomyces cerevisiae 424A(LNH-ST), and Zymomonas mobilis AX101 are compared side-by-side on corn steep liquor (CSL) media and the water extract and enzymatic hydrolysate from ammonia fiber expansion (AFEX)-pretreated corn stover.

Results: The three ethanologens are able produce ethanol from a CSL-supplemented co-fermentation at a metabolic yield, final concentration and rate greater than $0.42 \mathrm{~g} / \mathrm{g}$ consumed sugars, $40 \mathrm{~g} / \mathrm{L}$ and $0.7 \mathrm{~g} / \mathrm{L} / \mathrm{h}(0-48 \mathrm{~h})$, respectively. Xylose-only fermentation of the tested ethanologenic bacteria are five to eight times faster than $424 \mathrm{~A}(\mathrm{LNH}-\mathrm{ST})$ in the CSL fermentation.

All tested strains grow and co-ferment sugars at $15 \% \mathrm{w} / \mathrm{V}$ solids loading equivalent of ammonia fiber explosion (AFEX)pretreated corn stover water extract. However, both $\mathrm{KO} 11$ and 424A(LNH-ST) exhibit higher growth robustness than AX101. In 18\% w/W solids loading lignocellulosic hydrolysate from AFEX pretreatment, complete glucose fermentations can be achieved at a rate greater than $0.77 \mathrm{~g} / \mathrm{L} / \mathrm{h}$. In contrast to results from fermentation in CSL, S. cerevisiae $424 \mathrm{~A}(\mathrm{LNH}-\mathrm{ST})$ consumed xylose at the greatest extent and rate in the hydrolysate compared to the bacteria tested.
\end{abstract}

Conclusions: Our results confirm that glucose fermentations among the tested strains are effective even at high solids loading ( $18 \%$ by weight). However, xylose consumption in the lignocellulosic hydrolysate is the major bottleneck affecting overall yield, titer or rate of the process. In comparison, Saccharomyces cerevisiae 424A(LNH-ST) is the most relevant strains for industrial production for its ability to ferment both glucose and xylose from undetoxified and unsupplemented hydrolysate from AFEX-pretreated corn stover at high yield.

\section{Background}

Lignocellulosic materials are renewable, abundant and economical carbon sources to potentially substitute for large amounts of petroleum for fuels and chemicals production $[1,2]$. Ethanol is generally expected to be the first major commercial product of this emerging cellulosic biofuels technology. Bioconversion of fermentable sugars to ethanol is of central importance to this technology $[3,4]$. Therefore, the development of microbial platforms

*Correspondence: bdale@egr.msu.edu

${ }^{1}$ Department of Chemical Engineering and Materials Science, DOE Great Lakes Bioenergy Research Center, Michigan State University, 3900 Collins Rd, Lansing, MI 48910, USA

Full list of author information is available at the end of the article has been extensively pursued to achieve cost-competitive ethanol yield, titer and productivity $[5,6]$.

Among the ethanologenic strains, Saccharomyces cerevisiae [7,8], Zymomonas mobilis [9] and Escherichia coli $[10,11]$ have been widely investigated and developed for cellulosic ethanol production. The unique advantages of the respective strains were discussed thoroughly in the relevant previous publications. An economically-attractive cellulosic technology almost certainly requires the strain to achieve ethanol yield, titer and rate higher than $90 \%, 40 \mathrm{~g} / \mathrm{L}(5.1 \% \mathrm{v} / \mathrm{v}), 1.0 \mathrm{~g} / \mathrm{L} / \mathrm{h}$, respectively [12]. The native capacity of the strains is not well-suited to fulfill those requirements for commercial cellulosic ethanol 
production. Thus, metabolic engineering approaches have been exploited in developing strains to effectively (i) uptake and metabolize pentoses $[6,13]$ and/or (ii) channel the carbon sources for ethanol production [14].

Despite the wealth of publications on strain development, efforts to compare their performance are often hampered by the variations in experimental conditions such as sugar type and concentration, media nutrient levels, initial cell density, feedstock pretreatment selection and detoxification (if applied)[15-17]. Differences in the nature of the pretreatment chemistries and degradation compound profiles strongly influence the performance of a fermenting strain [18]. A systematic and rigorous experimental framework is clearly required to compare the performance of the ethanologenic strains.

In this work, we establish a common platform to obtain comprehensive fermentation parameters using S. cerevisiae 424A(LNH-ST), Z. mobilis AX101 and E. coli KO11 as the fermenting strains. In addition, the effect of the water-soluble substances (mainly pretreatment-mediated reaction compounds) from ammonia fiber explosion (AFEX) pretreated corn stover on the growth and fermentation of these three strains is investigated. We also examine the fermentation of enzymatic hydrolysate from AFEX-pretreated corn stover at high solids loading.

\section{Methods}

\section{AFEX-pretreated corn stover (AFEX-CS)}

Corn stover (CS) was obtained from the National Renewable Energy Laboratory (NREL; Colorado, USA), milled and passed through a $4 \mathrm{~mm}$ screen. The untreated corn stover consisted of 33.2\% cellulose, $22.4 \%$ xylan, 3.3\% arabinan (analyzed using NREL LAP-002 protocol) and 2.3\% protein on a dry weight basis. The error (standard deviation of the triplicate analyzes) of the composition is within $1.5 \%$ of the average values. We determined the nitrogen content of the corn stover using a Skalar Primacs SN Total Nitrogen Analyzer (Breda, The Netherlands). The principle behind the nitrogen analysis is based on Dumas method using ethylenediaminetetraacetic acid as the standards. The nitrogen content was converted protein content by multiplying a factor of 6.25. We used the composition data to determine solids loading during enzymatic hydrolysis. The pretreatment conditions were as follows: temperature at $110-130^{\circ} \mathrm{C}$; catalyst loading at $1.0 \mathrm{~g}$ anhydrous ammonia to $1.0 \mathrm{~g}$ dry corn stover ratio; water loading at $0.6 \mathrm{~g}$ water to $1.0 \mathrm{~g}$ dry corn stover; and $15 \mathrm{~min}$ retention time. Each pretreatment batch contained 150 g corn stover on a dry weight basis. The AFEX apparatus, pretreatment conditions and experiment procedures were as reported [19]. The moisture content after overnight air-drying was about $7 \%$ on a total weight basis.

\section{Microbial strains}

Metabolically-engineered ethanologens used in this investigation are $S$. cerevisiae 424A(LNH-ST), Z. mobilis AX101 and E. coli KO11. Strains 424A(LNH-ST) and AX101 were provided by Purdue University and the NREL, respectively. E. coli KO11 was obtained from American Type Culture Collection with designated number 55124. Genetic modification and reported fermentation performance were previously reported $[9,10,13,20]$.

\section{Corn steep liquor (CSL)}

FermGold $^{\mathrm{TM}}$ CSL (Lot: 154-07) from Cargill Inc (MN, USA) was used as the nitrogen source for fermentation. Technical information from Cargill Inc indicated that FermGold $^{\mathrm{Tm}}$ CSL contained 48.0-52.0\% w/w dissolved solids and $19.5-23.5 \% \mathrm{w} / \mathrm{w}$ total protein. In order to prepare $20 \%$ w/v CSL, 200 g of FermGold ${ }^{\mathrm{Ts}}$ whole CSL was diluted to a total volume of $1.0 \mathrm{~L}$ with distilled water and $\mathrm{pH}$ was adjusted to 7.0 with reagent grade $\mathrm{KOH}$. The insoluble solids were separated from the liquid by centrifugation at $5000 \times \mathrm{g}$ for $30 \mathrm{~min}$. In $1 \mathrm{~kg}$ of the $20 \%$ CSL mixture, 19.0 $\pm 0.8 \mathrm{~g}$ of dry solids were removed after centrifugation. The $20 \% \mathrm{w} / \mathrm{v}$ CSL was sterile-filtered $(0.22 \mu \mathrm{m})$ and used for media preparation.

\section{AFEX-CS wash stream (WS) preparation}

AFEX-pretreated CS was washed with distilled water at a ratio of $1 \mathrm{~g}$ dry CS to $5 \mathrm{~mL}$ of water to produce a water extract at $20 \% \mathrm{w} / \mathrm{v}$ solids loading equivalent. In each batch of washing, distilled water was preheated to $60^{\circ}$ $70^{\circ} \mathrm{C}$ and added to $100 \mathrm{~g}$ (dry weight equivalent) of AFEXCS. The water content of the wetted AFEX-CS was reduced by using an in-house manufactured press. The washing was conducted in three cycles - water-extract from a previous cycle of washing was used for the next cycle of washing. In the final cycle of washing, the moisture content of the washed AFEX-CS was reduced to $77 \pm$ $3 \% \mathrm{w} / \mathrm{w}$ on a total weight basis. The AFEX-CS water extract was used for the fermentation studies.

\section{AFEX-CS enzymatic hydrolysate $6 \% \mathrm{w} / \mathrm{w}$ glucan loading ( $18 \% \mathrm{w} / \mathrm{w}$ solids loading)}

AFEX-CS was enzymatically-hydrolyzed using both cellulase and hemicellulase commercial mixtures. The cellulase mixture consisted of Spezyme ${ }^{\circ} \mathrm{CP}[86.7 \mathrm{~mL} / \mathrm{kg} \mathrm{CS} ; 15$ FPU/g cellulose] and Novozyme ${ }^{\mathrm{Tm}} 188$ [43.7 mL/kg CS; 32 $p$ NPGU/g cellulose]. The hemicellulase mixture was Multifect Xylanase $[12.7 \mathrm{~mL} / \mathrm{kg} \mathrm{CS}]$ and Multifect ${ }^{\circ}$ Pectinase $[8.9 \mathrm{~mL} / \mathrm{kg} \mathrm{CS}]$. Enzymatic hydrolysis was performed for $96 \mathrm{~h}$ at $\mathrm{pH} 4.8,50^{\circ} \mathrm{C}$ and $250 \mathrm{rpm}$ agitation. Phosphate buffer (final concentration $0.05 \mathrm{M}$ ) and $12 \mathrm{M}$ $\mathrm{HCl}$ at loading $0.02 \mathrm{~mL} / \mathrm{g}$ dry CS. The activity spectrum of the commercial enzymes used was as reported [21]. Other details were as described previously [22] 


\section{Seed culture preparation}

The frozen $\left(-80^{\circ} \mathrm{C}\right)$ glycerol stock was transferred to 100 $\mathrm{mL}$ liquid media (nitrogen source, $50 \mathrm{~g} / \mathrm{L}$ total sugar, appropriate buffer and antibiotics) in a $250 \mathrm{~mL}$ unbaffled flask. The cells were grown overnight under largely anaerobic conditions at their respective temperatures and initial pH, $150 \mathrm{rpm}$ agitation. Details of culture temperature, initial $\mathrm{pH}$, antibiotics, sugar levels and nitrogen source are as listed in Table 1. These conditions depend on the strain and the type of fermentation for which these seed cultures were prepared. In order to investigate the effect of adaptation of AX101 during seed culture on hydrolysate fermentation, $3 \%$ glucan loading of AFEX-CS hydrolysate (pH5.5) was used as seed culture media without nutrient supplementation.

\section{Fermentation using CSL as sole nitrogen source}

Fermentations were conducted in $\mathrm{pH}$-controlled fleaker fermentors, as described [23]. Each fleaker (200 mL working volume in $500 \mathrm{~mL}$ fleaker) was equipped with a $\mathrm{pH}$ probe, a needle to add fluids, a needle for sampling and a magnetic stir bar. A six-position magnetic-stirring plate was placed underneath a water bath to drive the bar at $150 \mathrm{rpm}$. Water temperature of the water was controlled through a recirculation heater at the respective temperature (Table 1). The fermentation media contained $2 \% \mathrm{w} / \mathrm{v}$ CSL, $100 \mathrm{~g} / \mathrm{L}$ total sugar, designated buffer and antibiotics. The designated volume of seed culture was centrifuged and the cell pellet was resuspended for an initial OD (600 nm) of 0.5 in the fermentor. Fermentations on glucose only, xylose only and a mixture of glucose and xylose at a mass ratio of 7:3 (co-fermentation) were investigated. Fermentation parameters such as cell density, metabolic ethanol yield, volumetric ethanol productivity and specific ethanol productivity were calculated as previously reported [24].
Fermentation using AFEX-CS enzymatic hydrolysate (6\%w/ w glucan loading)

Fermentation of the hydrolysate was conducted in shake flask (70 mL in $250 \mathrm{~mL}$ flask) as described [24] based on conditions for seed culture preparation listed in Table 1. Initial cell density was $0.5 \mathrm{OD}(600 \mathrm{~nm})$. Hydrolysate of AFEX treated corn stover was fermented without washing, detoxification or nutrient supplementation. Error bars shown in the results are standard deviations of duplicates.

\section{Microplate cell culture}

Fermentations of KO11, AX101 and 424A(LNH-ST) on $0.0 \%, 7.5 \%$ and $15.0 \% \mathrm{w} / \mathrm{v}$ solids-loading-equivalent AFEX-Wash Stream (AFEX-WS) were conducted in a 24well cell culture microplate (BD Falcon \#353047, San Jose, CA). Media was supplemented with $2 \%$ w/v CSL, $30 \mathrm{~g} / \mathrm{L}$ glucose and $20 \mathrm{~g} / \mathrm{L}$ xylose with appropriate buffer (Table 1). Each well contained $2.0 \mathrm{~mL}$ media and a glass bead (6 $\mathrm{mm}$ diameter) was added to aid stirring. Seed cultures were prepared as described above and the microplate cell culture was initiated at OD $(600 \mathrm{~nm})$ of 0.5 . The microplate was sealed and fixed in an incubator shaker (150 rpm) by using a microplate clamp system (Applikon Inc, Springfield, IL). An opening (about $1 \mathrm{~mm}$ ) was made on the seal to allow carbon dioxide produced to escape. The culture temperatures and $\mathrm{pH}$ were as shown in Table 1. After $24 \mathrm{hr}$, fermentations were stopped and samples were taken. Error bars shown in the results are standard deviations of triplicates.

\section{Wash stream fermentation}

Fermentation was conducted with KO11 using 15.0\% w/v solids-loadings-equivalent of AFEX-WS with or without addition of commercial enzymes at loadings described in previous section [22]. The wash stream contains less than

Table 1: Seed culture media recipe for the three ethanologenic strains

\begin{tabular}{|c|c|c|c|c|c|}
\hline Strain & Temperature $\left({ }^{\circ} \mathrm{C}\right)$ & Buffer/pH & Antibiotics & $\begin{array}{l}\text { Sugars } \\
\text { concentration }\end{array}$ & Nitrogen source \\
\hline KO11 & 37 & $0.1 \mathrm{M} \mathrm{MOPS} / 7.0$ & $\begin{array}{l}50 \mathrm{mg} / \mathrm{L} \\
\text { Chloramphenicol }\end{array}$ & & \\
\hline AX101 & 30 & 0.05 M Phosphate/5.5 & $\begin{array}{l}30 \mathrm{mg} / \mathrm{L} \\
\text { Ampicillin }\end{array}$ & $\begin{array}{l}50 \mathrm{~g} / \mathrm{L} \text { for Glucose- } \\
\text { only and } \\
\text { fermentation } 30 \mathrm{~g} / \mathrm{L} \\
+20 \mathrm{~g} / \mathrm{L} \text { for co- } \\
\text { fermentation and } \\
\text { xylose-only }\end{array}$ & $\begin{array}{l}2.0 \% \mathrm{w} / \mathrm{v} \text { corn steep liquor } \\
(\mathrm{CSL}) \text { for fermentation in } \mathrm{CSL} \\
\text { fermentation; } 5.0 \mathrm{~g} / \mathrm{L} \text { yeast } \\
\text { extract }+10.0 \mathrm{~g} / \mathrm{L} \text { peptone for } \\
\text { wash stream and AFEX } \\
\text { hydrolysate fermentation }\end{array}$ \\
\hline 424A-(LNH-ST) & 30 & 0.05 M Phosphate/5.5 & $\begin{array}{l}50 \mathrm{mg} / \mathrm{L} \\
\text { Ampicillin }\end{array}$ & & \\
\hline
\end{tabular}

Note: yeast extract and peptone was only used for seed culture preparation but was not supplemented to the actual ammonia fiber explosion (AFEX)-corn stover hydrolysate during ethanol fermentation. 
$2.5 \mathrm{~g} / \mathrm{L}$ of monomeric glucose and xylose. YEP (yeast extract peptone; final concentration at $5 \mathrm{~g} / \mathrm{L}$ yeast extract, $10 \mathrm{~g} / \mathrm{L}$ paptone), $50 \mathrm{~g} / \mathrm{L}$ glucose and $25 \mathrm{~g} / \mathrm{L}$ xylose were added into the media mixtures. Fermentation was conducted at $37^{\circ} \mathrm{C}, \mathrm{pH} 7.0$, in a $125 \mathrm{~mL}$ shake flask with a 50 $\mathrm{mL}$ working volume. Initial cell density was at $0.5 \mathrm{OD}$ $(600 \mathrm{~nm})$. Error bars shown in the results are standard deviations of duplicates.

\section{HPLC analysis and cell density measurement}

The concentrations of glucose, xylose, ethanol, acetate, formate, lactate, glycerol and xylitol in the fermentation and culture experiments were analyzed using high-performance liquid chromatography (HPLC) with a Biorad Aminex HPX-87 H column (CA, USA). The column temperature was maintained at $60^{\circ} \mathrm{C}$ and the mobile phase $(5$ $\mathrm{mM} \mathrm{H}_{2} \mathrm{SO}_{4}$ ) was kept at $0.6 \mathrm{~mL} / \mathrm{min}$ flow rate. The HPLC system used was as reported [24]. Cell densities were measured using a UV/Vis Spectrophotomer (Beckmann Coulter DU720) at wavelength $600 \mathrm{~nm}$. The absorbance reading was converted to the unit of $g$ dry-wt/L. One unit of absorbance at wavelength $600 \mathrm{~nm}$ is equivalent to 0.31 , 0.47, $0.33 \mathrm{~g}$ dry-wt/L for Z. mobilis AX101, S. cerevisiae 424A(LNH-ST) and E. coli KO11, respectively.

\section{Results}

\section{Fermentations using CSL as nutrients supplement}

Fermentations using 2\% w/v CSL as nitrogen source indicated that these three strains effectively produce ethanol from glucose or a mixture of glucose and xylose. During glucose fermentation, the fermentations were completed within $72 \mathrm{~h}$ (Figure 1A) and ethanol was produced at concentrations higher than $40 \mathrm{~g} / \mathrm{L}$. In particular, 424A(LNHST) had the highest rate of glucose utilization at $4.16 \mathrm{~g} / \mathrm{L} /$ $\mathrm{h}$ (Figure 1A). However, an increase in xylose concentration correlated with a decrease of the overall fermentation rate. Overall sugar consumption rates compared between the glucose and xylose fermentation were closest for KO11 followed by AX101 and then 424A(LNH-ST) (Figure 1A and 1C; Table 2). Remarkably, xylose fermentation in $424 \mathrm{~A}(\mathrm{LNH}-\mathrm{ST})$ achieved only $37.9 \%$ of xylose consumption after $168 \mathrm{~h}$. Nevertheless, xylose fermentation by $424 \mathrm{~A}(\mathrm{LNH}-\mathrm{ST})$ was completed when using YEP as the nutrient supplement (Table 2). Specific ethanol productivities of fermentations using the bacteria (AX101 and $\mathrm{KO} 11$ ) as the fermenting strain were at least twice as great as those for 424A(LNH-ST), regardless the type of carbon source (Table 2).

\section{Metabolic ethanol yield and byproducts profiles}

For AX101 and 424A(LNH-ST), metabolic ethanol yield appeared to decrease in complete fermentation of xylosecontaining CSL media (Table 2). Carbon source (glucose or xylose) did not significantly affect the metabolic yield in KO11 fermentation. This trend was also reflected through the profile of targeted byproducts. The total concentrations of the targeted net-byproducts formation in xylose-containing fermentation increased for AX101 and 424A(LNH-ST) compared to glucose-only fermentation, but were essentially unchanged for KO11 (Figure 2).

In xylose-containing fermentation (both xylose only and co-fermentation) by AX101, xylitol is the primary byproduct and it contributed about 70\% (58 and $36 \mathrm{mg}$ xylitol/g consumed sugars, in the respective fermentation) of the total measured byproducts. In fermentation by $424 \mathrm{~A}(\mathrm{LNH}-\mathrm{ST})$, net productions of 67 and $81 \mathrm{mg}$ glyc$\mathrm{erol} / \mathrm{g}$ total consumed sugar(s) were observed in glucose and co-fermentation, respectively (Figure 2A and 2B). In addition, xylitol production during co-fermentation contributed to the lower metabolic yield observed compared to glucose-only fermentation.

Organic acids were identified as the predominant group of byproducts from fermentation by KO11 (Figure 2 ). Although total concentrations of the targeted byproducts were at 6.0-6.5 g/L regardless of carbon source, the byproduct profile varied substantially. While acetate formation increased from 21.4 (glucose-only) to $47.5 \mathrm{mg} / \mathrm{g}$ consumed sugar (xylose-only), lactate production diminished during xylose-only fermentation. Of all fermentations, glucose fermentation by AX101 achieved the highest metabolic yield (Table 2) and lowest targeted byproduct formation.

\section{Fermentation using AFEX-CS wash stream}

AFEX-CS wash stream was used to provide a representative compound profile found in the pretreated biomass without the involvement of enzymatic hydrolysis. Fermentations by these three strains exhibited similar patterns; in that moderate levels of AFEX-CS wash stream improved cell growth but the degree of improvement decreased as the strength of the wash stream increased. However, a greater cell density was achieved in most of the wash stream-containing fermentations relative to the control (YEP with no wash stream; Figure 3A).

The rate of xylose fermentation correlated well with the cell growth pattern (Figure 3).

KO11 consumed xylose completely at the highest rate (close to $20 \mathrm{~g} / \mathrm{L} / \mathrm{h}$ ) at $5 \% \mathrm{w} / \mathrm{v}$ solids loading equivalent of wash stream. However, the rate decreased substantially as the solids loading equivalent increased. In the highest tested solids loading, $424 \mathrm{~A}(\mathrm{LNH}-\mathrm{ST})$ had the greatest xylose consumption rate $(12.8 \mathrm{~g} / \mathrm{L} / \mathrm{h})$ followed by $\mathrm{KO} 11$ and AX101.

Although able to ferment at the highest specific rate (g/ $\mathrm{h} / \mathrm{g}$ cells), AX101 consumed both sugars at the lowest volumetric rate. AX101 also appeared to have the lowest tolerance toward water-soluble compounds in AFEX-CS. The cell density of AX101 at 24 h decreased by $66 \%$ when 

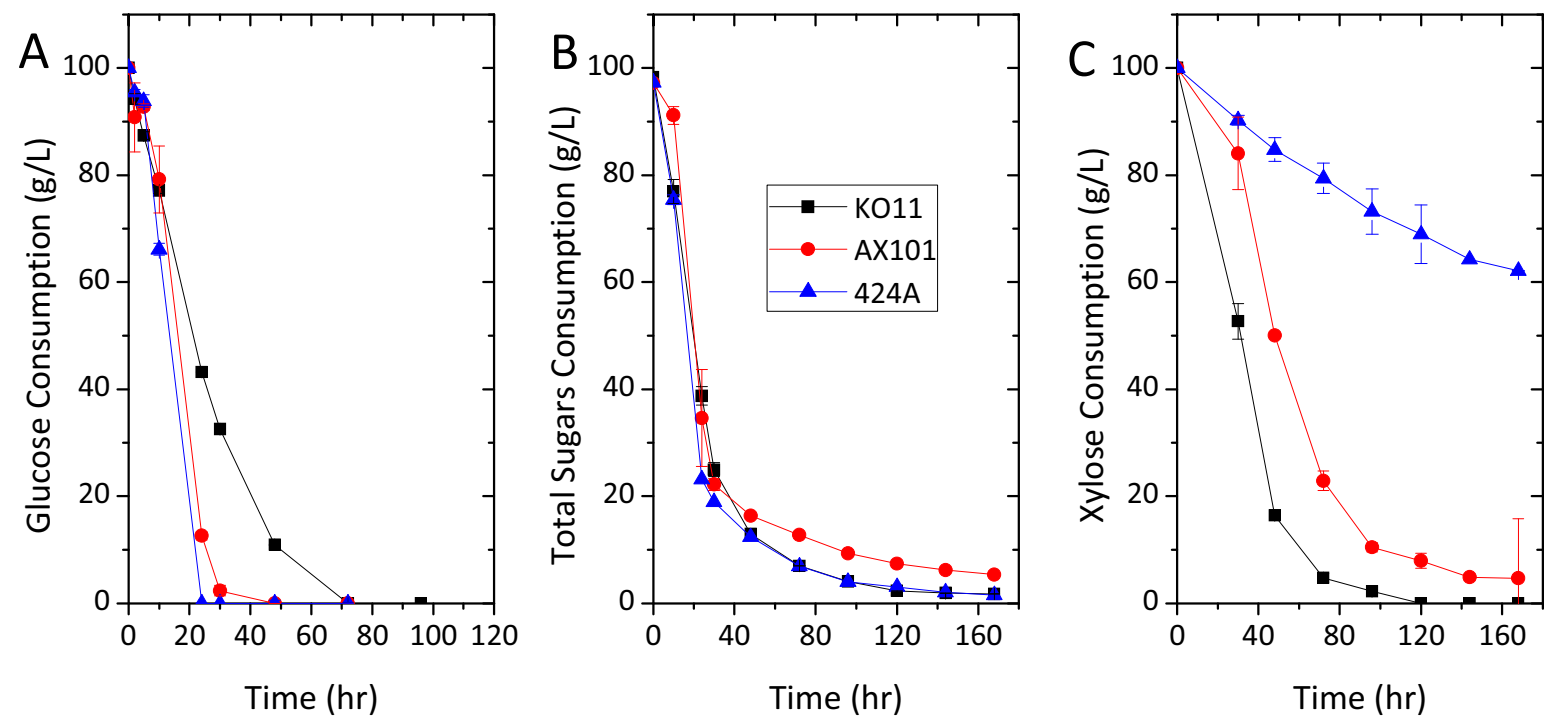

Figure 1 Fermentation using Escherichia coli KO11, Zymomonas mobilis mobilis AX101 and Saccharomyces cerevisiae 424A(LNH-ST) in 2\% w/v corn steep liquor with (A) glucose as sole carbon source, (B) glucose and xylose mixture ratio 7:3 and (C) xylose as sole carbon source. Fermentation was conducted in the fleaker fermentor under largely anaerobic condition and initiated cell density equivalent to $0.5 \mathrm{units}$ OD600 $\mathrm{nm}$. Temperature and $\mathrm{pH}$ were controlled at $37^{\circ} \mathrm{C}, 6.8$ for $\mathrm{KO} 11$ and $30^{\circ} \mathrm{C}, 5.5$ for $\mathrm{AX} 101$ and $424 \mathrm{~A}(\mathrm{LNH}-\mathrm{ST})$.

the solids loading was increased from $5 \%$ to $15 \% \mathrm{w} / \mathrm{w}$ (Figure 3A). This decrease for both $424 \mathrm{~A}(\mathrm{LNH}-\mathrm{ST})$ and KO11 was $26 \%$.

The effect of water soluble degradation compounds from AFEX-CS at $15 \% \mathrm{w} / \mathrm{v}$ solids loading equivalent on glucose fermentation was practically negligible for KO11 (Figure 4). However, these compounds were shown to be rather inhibitory toward xylose fermentation (Figure 4). The xylose consumption rate within $96 \mathrm{~h}$ in wash stream fermentation was five times lower than that of the control experiment.

\section{Fermentation using AFEX-CS hydrolysate ( $18 \% \mathrm{w} / \mathrm{w}$ solids loading) and AFEX-CS WS}

All tested strains were able to grow and completely consume glucose on the AFEX-CS hydrolysate without washing of the pretreated biomass, nutrient supplementation or detoxification (Figure 5). Similar to co-fermentation in CSL (Figure 1B, Table 3), xylose fermentation was considerably slower than glucose fermentation. In the hydrolysate fermentation, xylose fermentation from the tested bacteria (AX101 and KO11) was very poor; less than 20\% of the total xylose was consumed (Figure 5A and 5C; Table 3). Hence, xylose fermentation became the bottleneck for yield, concentration and rate for the bacteria. However, nearly complete xylose consumption was achieved in $424 \mathrm{~A}(\mathrm{LNH}-\mathrm{ST})$ fermentation at a metabolic yield of $0.47 \mathrm{~g}$ ethanol $/ \mathrm{g}$ consumed sugars.

\section{Discussion}

\section{Rationale behind the platform for comparison}

In this work, we first compared glucose, xylose and cofermentation in the CSL, followed by co-fermentations on AFEX-CS enzymatic hydrolysate to elucidate its effects on microbial growth pattern and xylose utilization. Fermentations using CSL reveal fermentation performance of respective ethanologens without the interference from degradation products from the pretreated biomass. CSL has also been regarded as a economical nitrogen source in large scale fermentation [25]. Lignocellulosic hydrolysate from AFEX-CS without washing, detoxification and supplementation provided the actual lignocellulosic sugar media for cellulosic ethanol production. This investigation platform would enable us to evaluate the strains based on their intrinsic fermentation ability and robustness for industrial applications.

Intrinsic fermentation performance of $E$. coli KO11, Z. mobilis AX101 and S. cerevisiae 424A(LNH-ST) in CSL media E. coli KO11, Z. mobilis AX101 and S. cerevisiae $424 \mathrm{~A}(\mathrm{LNH}-\mathrm{ST})$ were able to produce ethanol with a metabolic yield between $82.4-93.2 \%$ of theoretical maximum (Table 2) in both glucose and co-fermentation at final concentrations of $40 \mathrm{~g} / \mathrm{L}$ or higher, at a rate over $0.72 \mathrm{~g} / \mathrm{L} /$ h (0-48 h). These parameters are comparable to those projected to be necessary for a viable cellulosic ethanol industry [12]. 
Table 2: Results for fermentation using Escherichia coli K011, Zymomonas mobilis mobilis AX101 and Saccharomyces cerevisiae 424A(LNH-ST) in 2\% w/w corn steep liquor (CSL) or yeast extract peptone (YEP)

\begin{tabular}{|c|c|c|c|c|c|c|c|c|c|c|}
\hline \multirow{2}{*}{$\begin{array}{l}\text { Nutrients } \\
\text { Source/sugar } \\
\text { Type }\end{array}$} & \multirow{2}{*}{$\begin{array}{l}\text { Concentration } \\
\text { (g/L) }\end{array}$} & \multirow[t]{2}{*}{ Strain } & \multirow{2}{*}{$\begin{array}{l}\text { Sugar } \\
\text { consumption (\%)* }\end{array}$} & \multirow{2}{*}{$\begin{array}{l}\text { Metabolic } \\
\text { EtOH yield } \\
(\%)^{* \dagger}\end{array}$} & \multirow{2}{*}{$\begin{array}{l}\text { Carbon } \\
\text { balance } \\
\text { coverage } \neq\end{array}$} & \multirow{2}{*}{$\begin{array}{l}\text { EtOH } \\
\text { Concentration* }\end{array}$} & \multicolumn{3}{|c|}{ Volumetric productivity (g/L/hr)† } & \multirow{2}{*}{$\begin{array}{l}\text { Specific } \\
\text { productivity } \\
\text { (g/L/h/g cell) } \\
0--48 \mathbf{~}\end{array}$} \\
\hline & & & & & & & Glc 0-24 h & Xyl 0-48 h & EtOH 0-48 h & \\
\hline & & KO11 & $100.0 \pm 0.0$ & $87.0 \pm 0.9$ & $97.3 \pm 1.1$ & $44.3 \pm 0.5$ & $-2.37 \pm 0.00$ & N/A & 0.79 & $0.57 \pm 0.03$ \\
\hline \multirow[t]{3}{*}{ CSL/glucose } & 100 & AX101 & $100.0 \pm 0.0$ & $93.2 \pm 0.1$ & $95.1 \pm 0.1$ & $47.5 \pm 0.1$ & $-3.64 \pm 0.13$ & $\mathrm{~N} / \mathrm{A}$ & 0.97 & $0.77 \pm 0.07$ \\
\hline & & 424A(LHN-ST) & $100.0 \pm 0.0$ & $85.2 \pm 0.5$ & $95.8 \pm 0.4$ & $43.5 \pm 0.3$ & $-4.16 \pm 0.03$ & N/A & 0.87 & $0.16 \pm 0.00$ \\
\hline & & KO11 & $98.2 \pm 0.5$ & $85.1 \pm 1.1$ & $95.9 \pm 1.1$ & $41.9 \pm 0.8$ & $-2.16 \pm 0.07$ & $-0.38 \pm 0.03$ & $+0.72 \pm 0.01$ & $0.55 \pm 0.00$ \\
\hline \multirow{3}{*}{$\begin{array}{l}\text { CSL/glucose + } \\
\text { xylose }\end{array}$} & $70+30$ & AX101 & $94.5 \pm 2.4$ & $88.6 \pm 0.0$ & $96.0 \pm 0.0$ & $41.5 \pm 1.1$ & $-2.43 \pm 0.37$ & $-0.29 \pm 0.05$ & $+0.77 \pm 0.02$ & $0.69 \pm 0.02$ \\
\hline & & 424A(LHN-ST) & $98.4 \pm 0.5$ & $82.4 \pm 0.5$ & $100.3 \pm 0.5$ & $40.2 \pm 0.1$ & $-2.76 \pm 0.08$ & $-0.39 \pm 0.04$ & $+0.73 \pm 0.01$ & $0.13 \pm 0.00$ \\
\hline & & KO11 & $100.0 \pm 0.0$ & $85.1 \pm 0.0$ & $93.6 \pm 0.2$ & $43.1 \pm 0.1$ & $\mathrm{~N} / \mathrm{A}$ & $-1.74 \pm 0.02$ & $+0.72 \pm 0.01$ & $0.54 \pm 0.00$ \\
\hline \multirow[t]{2}{*}{ CSL/Xylose } & 100 & AX101 & $95.3 \pm 0.1$ & $84.9 \pm 0.2$ & $97.1 \pm 0.1$ & $41.3 \pm 0.1$ & N/A & $-1.04 \pm 0.01$ & $+0.42 \pm 0.00$ & $0.46 \pm 0.01$ \\
\hline & & 424A(LHN-ST) & $37.9 \pm 6.5$ & $89.8 \pm 1.3$ & $93.2 \pm 0.9$ & $18.1 \pm 3.2$ & $\mathrm{~N} / \mathrm{A}$ & $-0.32 \pm 0.05$ & $+0.09 \pm 0.02$ & $0.10 \pm 0.00$ \\
\hline YEP§/xylose & 100 & 424A(LHN-ST) & $100.0 \pm 0.0$ & $92.0 \pm 0.01$ & N/A & $46.9 \pm 0.0$ & N/A & $-1.77 \pm 0.02$ & $+0.87 \pm 0.01$ & $0.11 \pm 0.00$ \\
\hline
\end{tabular}

*Time-span for the calculated data: Glc fermentation 0-72 h; Xyl and co-fermentation 0-168 h.

tThe method to calculate metabolic yields and productivities were as reported in Ref [24].

${ }^{\ddagger}$ Carbon balance covers ethanol, carbon dioxide and all the selected by-products formed during fermentation relative to carbon in consumed sugars. Carbon dioxide production was estimated

through the stoichiometric equation for the fermentation of glucose to ethanol - ethanol and carbon dioxide were produced on an equimolar basis.

§Yeast extract peptone (YEP), $10 \mathrm{~g} / \mathrm{L}$ bacto yeast extract $+20 \mathrm{~g} / \mathrm{L}$ bacto peptone.

CSL, corn steep liquor; NA, not applicable. 

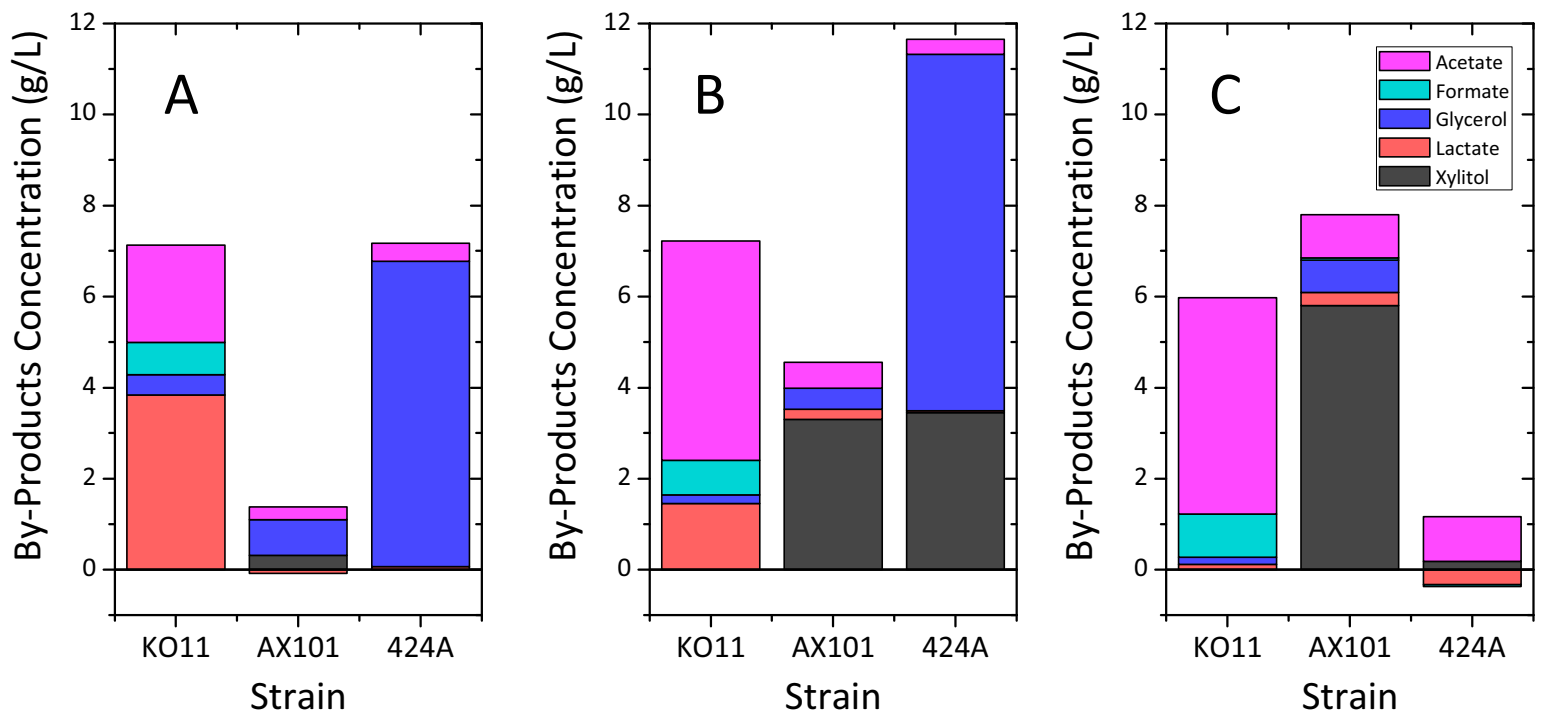

Figure 2 By-products concentration during (A) glucose fermentation at $72 \mathrm{~h},(\mathrm{~B})$ co-fermentation at $168 \mathrm{~h}$ and (C) Xylose fermentation at $168 \mathrm{~h}$, in corn steep liquor using Escherichia coli KO11, Zymomonas mobilis mobilis AX101 and Saccharomyces cerevisiae 424A(LNH-ST).

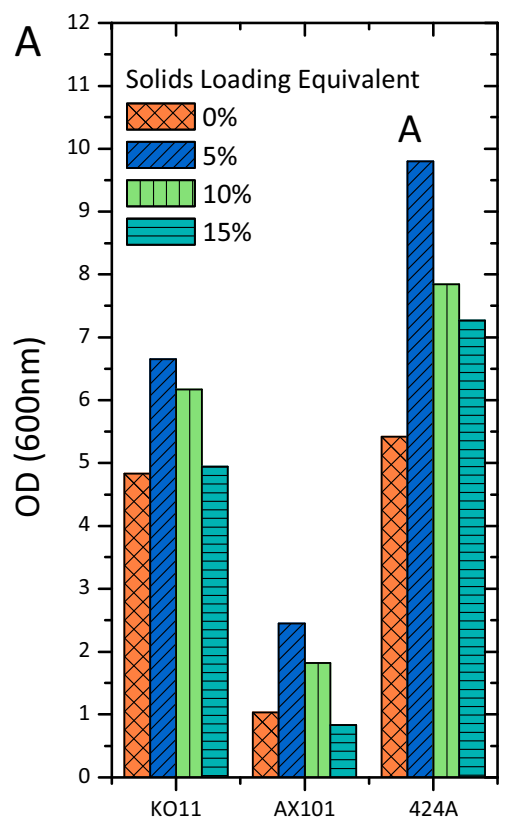

Ethanologenic Strains

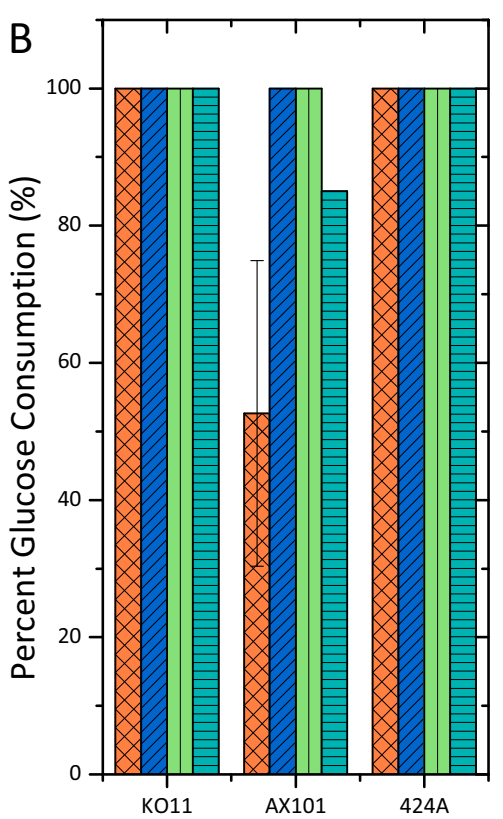

Ethanologenic Strain

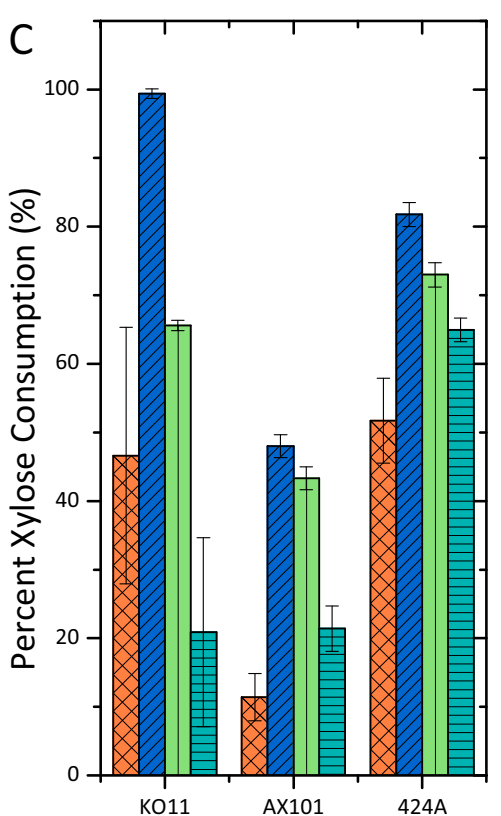

Ethanologenic Strain

Figure 3 The effect of water-soluble compounds from ammonia fiber explosion (AFEX)-treated corn stover on (A) cell growth, (B) percent glucose consumption and (C) percent xylose consumption after $\mathbf{2 4} \mathbf{h}$ fermentation. The experiments were conducted in 24 wells plate at 2.0 $\mathrm{mL}$ working volume under largely anaerobic condition. The initial concentration of glucose, xylose and cell density was $3 \mathrm{~g} / \mathrm{L}, 20 \mathrm{~g} / \mathrm{L}$ and $0.5 \mathrm{unit}$ of OD600 $\mathrm{nm}$, respectively. The fermentation media was supplemented with $2.5 \mathrm{~g} / \mathrm{L}$ yeast extract and $5 \mathrm{~g} / \mathrm{L}$ peptone. 


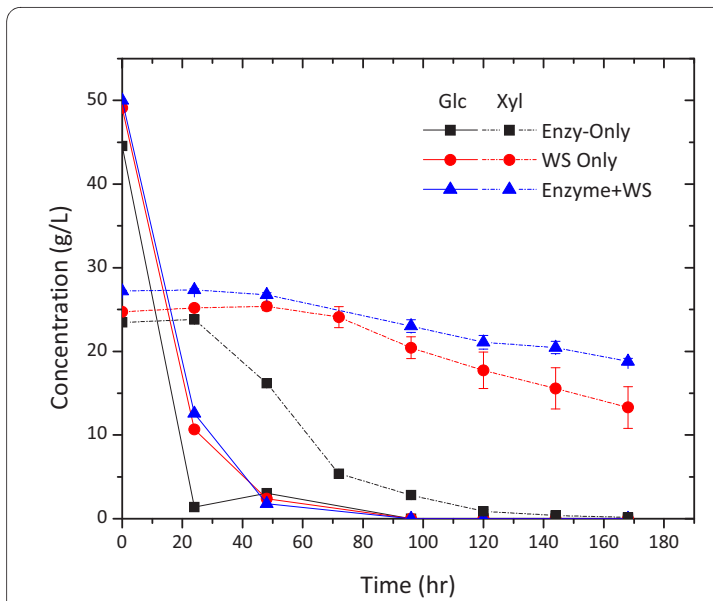

Figure 4 Fermentation using Escherichia coli KO11 on yeast extract peptone ( $5 \mathrm{~g} / \mathrm{L}$ yeast extract $+10 \mathrm{~g} / \mathrm{L}$ peptone) media supplemented with commercial enzymes, $15 \%$ solids loading equivalent of ammonia fiber explosion (AFEX)-corn stover wash stream (WS) or a combination of commercial enzymes and the WS. Fermentation was conducted at $37^{\circ} \mathrm{C}, \mathrm{pH} 7.0$ (adjusted during fermentation) and was initiated at $0.5 \mathrm{OD} 600 \mathrm{~nm}$.

Regardless of media used, fermentations with higher glucose to xylose ratios yielded better results in term of ethanol yield, concentration and rate. Pentose-only fermentation in naturally-occurring xylose-metabolizing strain, such as $E$. coli, has proven to be more difficult than hexose fermentation. One proven cause is the lack of pre- cursors to synthesize products derived from 2-ketoglutarate[26]. In the heterologous pentose metabolic system, additional issues associated with pentose transport [27] and redox balance $[6,8]$ are also reported as potential bottlenecks for xylose-to-ethanol bioconversion.

\section{Xylose fermentation in AFEX-CS hydrolysate}

In this report, xylose fermentation in lignocellulosic hydrolysate is shown to be substantially more challenging relative to co-fermentation in CSL. Furthermore, xylose consumption in the bacterial fermentations was considerably weaker than in $424 \mathrm{~A}(\mathrm{LNH}-\mathrm{ST})$ fermentation. The selective inhibition on the xylose fermentations, presumably from degradation products from pretreated biomass, is not well understood. Hence, improved fundamental understanding of the inhibitory mechanism selectively targets xylose fermentations could help alleviate this crucial process bottleneck.

\section{Relative strengths and weaknesses of the individual ethanologenic strains}

$\mathrm{KO} 11$ is able to tolerate a relatively high concentration of AFEX-CS degradation compounds and produces ethanol at a high metabolic yield and rate. Nevertheless, xylose utilization in degradation compound-containing media (high solids loading) is severely affected (Figure 5). AX101 is an excellent ethanologenic strain due to its superior metabolic yield and glucose fermentation rate (Table 3). However, the growth robustness of this strain
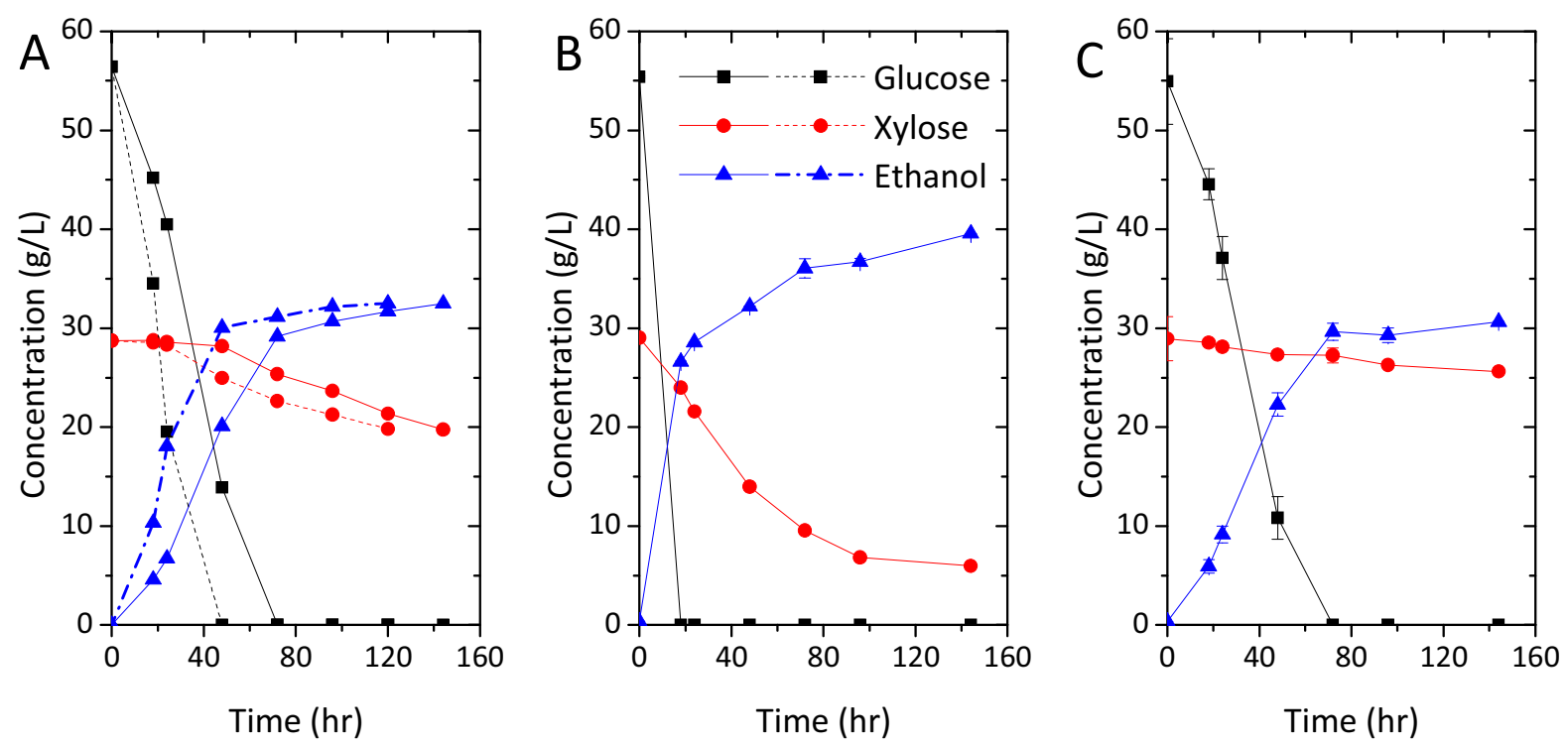

Figure 5 Fermentation using (A) Zymomonas mobilis mobilis AX101, (B) Saccharomyces cerevisiae 424A(LNH-ST) and (C) Escherichia coli KO11, in enzymatic hydrolysate from $6.0 \%$ glucan loading of ammonia fiber explosion (AFEX)-pretreated corn stover (CS). Fermentation was conducted under largely anaerobic condition and initiated at cell density equivalent to 0.5 unit OD600 nm temperature and pH were controlled at $37^{\circ} \mathrm{C}, 6.8$ for $\mathrm{KO} 11$ and $30^{\circ} \mathrm{C}, 5.5$ for AX101 and $424 \mathrm{~A}(\mathrm{LNH}-\mathrm{ST})$. Solid lines: Seed culture in yeast extract peptone; dotted lines: seed culture in $3 \%$ glucan loading of AFEX-CS hydrolysate. 
Table 3: Qualitative summary of the relative fermentation performance of Zymomonas mobilis mobilis AX101, Saccharomyces cerevisiae 424A(LNH-ST) and Escherichia coli

\begin{tabular}{|c|c|c|c|c|}
\hline Fermentation & Parameters & AX101 & 424A & K011 \\
\hline \multirow{2}{*}{$\begin{array}{l}\text { Glucose } \\
\text { Consumption }\end{array}$} & In corn steep liquor (CSL) & Very fast & Very fast & Fast \\
\hline & In lignocellulosic hydrolysate & Average & Very fast & Average \\
\hline \multirow[t]{2}{*}{ Xylose Consumption } & In CSL co-fermentation & Average & Very slow & Fast \\
\hline & In lignocellulosic hydrolysate & Very slow & Average & Very slow \\
\hline \multirow[t]{3}{*}{ Nutrient Requirement } & Glucose-only & Low & Low & Low \\
\hline & Co-Fermentation & Low & Low & Low \\
\hline & Xylose-only & Average & High & Low \\
\hline \multicolumn{2}{|c|}{ Growth Robustness } & Average & Very High & High \\
\hline \multicolumn{2}{|c|}{ Metabolic Yield } & Very High & High & High \\
\hline
\end{tabular}

in the media containing degradation products is the lowest among the tested strain. S. cerevisiae 424A(LNH-ST) is highly robust and able to ferment both glucose and xylose to ethanol reasonably well (greater than $85 \%$ of ethanol yield), even at high solids loading (Figure 5).

By comparing these three strains, $S$. cerevisiae 424A(LNH-ST) appears to be the most relevant strain for industrial production due to the overall ethanol yield, titer and rate achieved by this strain in undetoxified and unsupplemented AFEX-CS hdyrolysate.

\section{Conclusions}

The intrinsic fermentation performance of all tested ethanologenic strains can fulfill the basic requirements for commercial cellulosic ethanol production. The bacterial metabolic pathway (KO11 and AX101) is more effective at fermenting ethanol from consumed sugars relative to the yeast (424A[LNH-ST]) pathway. However, xylose fermentation is selectively affected during fermentation of pretreated corn stover hydrolysate; the ability to consume xylose in lignocellulosic hydrolysate is the determining factor that dictates overall process yield and concentration. In this regard, S. cerevisiae 424A(LNH-ST) has shown the highest xylose consumption extent and rate among tested ethanologens.

\section{Abbreviations}

AFEX: ammonia fiber expansion; AFEX-WS: AFEX-CS wash stream; CS: corn stover; CSL: corn steep liquor; NREL: National Renewable Energy Laboratory; YEP: yeast extract peptone.

\section{Competing interests}

The authors declare that they have no competing interests.

\section{Authors' contributions}

MWL designed and carried out experiments, analyzed results and wrote the manuscript. CG carried out experiments and analyzed results. VB and BED analyzed results and reviewed the manuscript. All authors have read and approved the final manuscript.

\section{Acknowledgements}

This work was financially supported by US Department of Energy through the DOE Great Lakes Bioenergy Research Center (GLBRC) Grant DE-FC0207ER64494. Spezyme and Multifect enzymes are provided by Genencor Inc The authors are grateful to Purdue University and the National Renewable Energy Laboratory for granting access to 424A(LNH-ST) strain and AX101. Thanks are due to the members of the Biomass Conversion Research Laboratory at Michigan State University for general assistance in the research work, particularly Derek Marshall and Charles Donald Jr who prepared the AFEX-pretreated corn stover. We are also grateful to Genencor Inc and Cargill Inc for supplying enzymes and FermGold ${ }^{\mathrm{TM}}$ corn steep liquor, respectively

\section{Author Details}

Department of Chemical Engineering and Materials Science, DOE Great Lakes Bioenergy Research Center, Michigan State University, 3900 Collins Rd, Lansing, MI 48910, USA

Received: 15 August 2009 Accepted: 27 May 2010

Published: 27 May 2010 


\section{References}

1. Lynd LR, Cushman JH, Nichols RJ, Wyman CE: Fuel ethanol from cellulosic biomass. Science 1991, 251:1318-1323.

2. Greene N, Celik FE, Dale B, Jackson M, Jayawardhana K, Jin H, Larson ED, Laser M, Lynd L, MacKenzie D: Growing Energy: How Biofuels Can Help End America's Oil Dependence. New York: Nature Resources Defense Council; 2004.

3. Jeffries TW: Ethanol fermentation on the move. Nature Biotech 2005, 23:40-41.

4. Lynd LR, Laser MS, Bransby D, Dale BE, Davison B, Hamilton R, Himmel M, Keller M, McMillan JD, Sheehan J, Wyman CE: How biotech can transform biofuels. Nat Biotechnol 2008, 26:169-172

5. Ingram LO, Gomez PF, Lai X, Moniruzzaman M, Wood BE, Yomano LP, York SW: Metabolic engineering of bacteria for ethanol production. Biotechnol Bioengineering 1998, 58:204-214.

6. Jeffries TW, Jin YS: Metabolic engineering for improved fermentation of pentoses by yeasts. Applied Microbiol Biotechnol 2004, 63:495-509.

7. Sedlak M, Ho NWY: Production of ethanol from cellulosic biomass hydrolysates using genetically engineered Saccharomyces yeast capable of cofermenting glucose and xylose. Applied Biochem Biotechnol 2004, 113-116:403-416.

8. Karhumaa K, Sanchez RG, Hahn-Hagerdal B, Gorwa-Grauslund MF: Comparison of the xylose reductase-xylitol dehydrogenase and the xylose isomerase pathways for xylose fermentation by recombinant Saccharomyces cerevisiae. Microbial Cell Factories 2007, 6:5.

9. Zhang M, Eddy C, Deanda K, Finkelstein M, Picataggio S: Metabolic Engineering of a pentose metabolism pathway in ethanologenic Zymomonas mobilis. Science 1995, 267:240-243.

10. Ohta K, Beall DS, Mejia JP, Shanmugam KT, Ingram LO: Genetic improvement of Escherichia coli for ethanol production - chromosomal integration of Zymomonas mobilis genes encoding pyruvate decarboxylase and alcohol dehydrogenase II. Applied Environmental Microbiol 1991, 57:893-900.

11. Yomano LP, York SW, Ingram LO: Isolation and characterization of ethanol-tolerant mutants of Escherichia coli KO11 for fuel ethanol production. J Ind Microbiol Biotechnol 1998, 20:132-138.

12. Dien BS, Cotta MA, Jeffries TW: Bacteria engineered for fuel ethanol production: current status. Applied Microbiol Biotechnol 2003, 63:258-266

13. Deanda K, Zhang M, Eddy C, Picataggio S: Development of an arabinosefermenting Zymomonas mobilis strain by metabolic pathway engineering. Applied Environment Microbiol 1996, 62:4465-4470.

14. Underwood SA, Zhou S, Causey TB, Yomano LP, Shanmugam KT, Ingram LO: Genetic changes to optimize carbon partitioning between ethanol and biosynthesis in ethanologenic Escherichia coli. Applied Environment Microbio/ 2002, 68:6263-6272.

15. Saha BC, Iten LB, Cotta MA, Wu YV: Dilute acid pretreatment, enzymatic saccharification and fermentation of wheat straw to ethanol. Process Biochem 2005, 40:3693-3700.

16. Ohgren K, Bengtsson O, Gorwa-Grauslund MF, Galbe M, Hahn-Hagerdal B, Zacchi G: Simultaneous saccharification and co-fermentation of glucose and xylose in steam-pretreated corn stover at high fiber content with Saccharomyces cerevisiae TMB3400. J Biotechnol 2006, 126:488-498.

17. Moniruzzaman M, Ingram LO: Ethanol production from dilute acid hydrolysate of rice hulls using genetically engineered Escherichia coli. Biotechnol Lett 1998, 20:943-947.

18. Lynd LR: Overview and evaluation of fuel ethanol from cellulosic biomass: Technology, economics, the environment, and policy. Ann Rev Energy Environment 1996, 21:403-465.

19. Teymouri F, Laureano-Perez L, Alizadeh H, Dale BE: Ammonia fiber explosion treatment of corn stover. Applied Biochem Biotechnol 2004, 113-116:951-963

20. Ho NW, Chen Z, Brainard AP, Sedlak M: Successful design and development of genetically engineered Saccharomyces yeasts for effective cofermentation of glucose and xylose from cellulosic biomass to fuel ethanol. Adv Biochem Eng Biotechnol 1999, 65:163-192.

21. Dien BS, Ximenes EA, O'Bryan PJ, Moniruzzaman M, Li XL, Balan V, Dale B, Cotta MA: Enzyme characterization for hydrolysis of AFEX and liquid hot-water pretreated distillers' grains and their conversion to ethanol. Bioresource Technol 2008, 99:5216-5225.
22. Lau MW, Dale BE: Cellulosic ethanol production from AFEX-treated corn stover using Saccharomyces cerevisiae 424A(LNH-ST). Proc Nat I Acad Sci USA 2009, 106:1368-1373

23. Beall DS, Ohta K, Ingram LO: Parametric studies of ethanol production form xylose and other sugars by recombinant Escherichia coli. Biotechnol Bioengineering 1991, 38:296-303.

24. Lau MW, Dale BE, Balan V: Ethanolic fermentation of hydrolysates from ammonia fiber expansion (AFEX) treated corn stover and distillers grain without detoxification and external nutrient supplementation. Biotechnol Bioengineering 2008, 99:529-539.

25. Lawford HG, Rousseau JD: Corn steep liquor as a cost-effective nutrition adjunct in high-performance Zymomonas ethanol fermentations. Applied Biochem Biotechnol 1997, 63-5:287-304.

26. Underwood SA, Buszko ML, Shanmugam KT, Ingram LO: Flux through citrate synthase limits the growth of ethanologenic Escherichia coli KO11 during xylose fermentation. Applied Environmental Microbiol 2002, 68:1071-1081.

27. Sedlak M, Ho NW: Characterization of the effectiveness of hexose transporters for transporting xylose during glucose and xylose cofermentation by a recombinant Saccharomyces yeast. Yeast 2004 21:671-684

doi: 10.1186/1754-6834-3-11

Cite this article as: Lau et al., Comparing the fermentation performance of Escherichia coli KO11, Saccharomyces cerevisiae 424A(LNH-ST) and Zymomonas mobilis AX101 for cellulosic ethanol production Biotechnology for Biofuels 2010, 3:11

\section{Submit your next manuscript to BioMed Central and take full advantage of:}

- Convenient online submission

- Thorough peer review

- No space constraints or color figure charges

- Immediate publication on acceptance

- Inclusion in PubMed, CAS, Scopus and Google Scholar

- Research which is freely available for redistribution
C) Biomed Central 